4. Byrd J. A., Bruce A. J., Rogers R. S. Glossitis and other tongue disorders. Dermatol. Clin. 2003. Vol. 21, № 1. P. 123-134

5. Stähler F., Brennick M.J., Delikatny J. Tongue Fat Infiltration in Obese Versus Lean Zucker Rats. Sleep. 2014. Vol. 37, № 6. P. 1095-1102.

DOI https://doi.org/10.30525/978-9934-26-113-8-22

\title{
КРАНІОМЕТРІЯ ЧЕРЕПА ТА ЛИЦЯ ПЛОДІВ І НОВОНАРОДЖЕНИХ
}

\author{
Костюк В. О.
}

аспірант кафедри анатомії, клінічної анатомії та оперативної хірургї

Буковинський державний медичний університет

\section{Слободян О. М.}

доктор медичних наук, професор,

завідувач кафедри анатомії, клінічної анатомії та оперативної хірургіі

Буковинський державний медичний університет

Лаврів Л. П.

кандидат медичних наук,

старший викладач кафедри анатомії, клінічної анатомії та

оперативної хірургії

Буковинський державний медичний університет

\section{Столяр Д. Б.}

кандидат медичних наук,

асистент кафедри гістології, ичтологї̈ та ембріології

Буковинський державний медичний університет

\section{Березина-Дундюк С. I.}

аспірант кафедри анатомії, клінічної анатомії та оперативної хірураї Буковинський державний медичний університет

$$
\text { м. Чернівиі, Україна }
$$

Розвиток нових методів дослідження, таких як ультразвукові та рентгенологічні методи (магнітно-резонансної томографії), формує поняття ультразвукової та рентгенологічної норми на різних етапах розвитку людини [1-5]. Важливе значення має прогнозування стану 
розташованих в цих утвореннях структур, можливих причин та наслідків їх, наприклад, компресійних уражень.

Матеріал та методи. Дослідження проведено на 57 препаратах плодів людини 4-10 місяців та 7 новонароджених (зокрема, 5 ізольованих органокомплексів) обох статей, без зовнішніх ознак анатомічних відхилень або аномалій та без явних макроскопічних відхилень від нормальної будови черепа за допомогою адекватних анатомічних методів: макропрепарування, виготовлення топографоанатомічних зрізів, комп'ютерна томографія, краніометрія. Краніометричне дослідження проводили в горизонтальній вушно-очній площині, в так названій «франкфуртській горизонталі», перед цим кожний об'єкт фіксували в краніостаті. Для дослідження використовували такі параметри лицевого та мозкового черепа: висота черепа, поперечна довжина черепа, загальна висота лиця, ширина лиця.

Перевірялась нульова гіпотеза про те, що вибірки взяті 3 одного розподілу, або з розподілів з однаковими медіанами:

$\mathrm{H}_{0}$ : \{кожна група має однаковий розподіл\}

$\mathrm{H}_{1}$ : \{кожна група не має однакового розподілу\}

Використовували тест Стьюдента, непараметричний критерій Краскела-Уолліса та тест Коновера-Імана. Статистично значущими вважали значення при $\mathrm{p}<0,05$.

Результати дослідження та їх обговорення. На основі проведених вимірювань встановлено, що у плодів 4 місяця внутрішньоутробного розвитку середнім показником поперечної довжини черепа є 45,13 $\pm 1,17$ мм, у плодів 5 місяця - 49,86 $\pm 0,17$ мм, у плодів 6 місяця $50,98 \pm 1,01$ мм, у плодів 7 місяців - 62,01 $\pm 2,78$ мм, у плодів 8 місяців $72,10 \pm 1,60$ мм, у плодів 9 місяців - 74,78 $\pm 0,83$ мм, у плодів 10 місяців $86,42 \pm 2,10$ мм та новонароджених $96,69 \pm 0,64$ мм.

Середні показники ширини лиця у плодів 4 місяця внутрішньоутробного розвитку становлять $35,23 \pm 0,37$ мм, у плодів 5 місяця $40,80 \pm 0,62$ мм, у плодів 6 місяця - 41,04 $\pm 1,28$ мм, у плодів 7 місяців $45,46 \pm 0,99$ мм, у плодів 8 місяців - 52,12 $\pm 2,75$ мм, у плодів 9 місяців $50,32 \pm 2,54$ мм, у плодів 10 місяців - 60,02 $\pm 2,03$ мм та новонароджених $64,09 \pm 0,29$ мм.

Встановлені середні показники висоти черепа у плодів та новонароджених, а саме, у плодів 4 місяців внутрішньоутробного розвитку висота черепа становить $46,79 \pm 0,74$ мм, у плодів 5 місяця $53,66 \pm 0,85$ мм, у плодів 6 місяця - 53,15 $\pm 1,55$ мм, у плодів 7 місяців $58,95 \pm 1,35$ мм, у плодів 8 місяців - 67,02 $\pm 3,24$ мм, у плодів 9 місяців - 
$63,52 \pm 0,56$ мм, у плодів 10 місяців - 71,42 $\pm 0,98$ мм та в новонароджених висота черепа дорівнює 73,04 $\pm 0,38$ мм.

Визначені середні показники загальної висоти лиця у плодів i новонароджених, а саме, у плодів 4 місяців внутрішньоутробного розвитку загальна висота лиця становить $25,23 \pm 0,52$ мм, у плодів 5 місяця - 28,03 $\pm 0,38$ мм, у плодів 6 місяця - 30,39 $\pm 0,81$ мм, у пло-

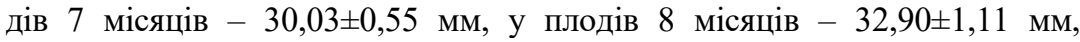

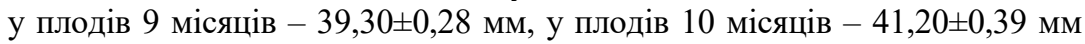

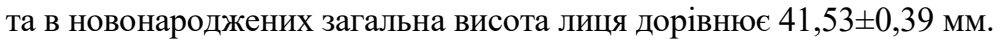

Провівши кореляційний зв'язок між всіма морфометричними параметрами черепа та лиця плодів і новонароджених з використанням коефіцієнту кореляції Пірсона, встановлено, що між значеннями усіх парних коефіцієнтів кореляції є додатними і досить близькими до 1 $(>0,90)$, що свідчить про тісний сильний позитивний кореляційний зв'язок між усіма морфометричними параметрами.

Порівнюючи дані середніх значень поперечної довжини черепа, ширини лиця, висоти черепа, загальної висоти лиця у плодів i новонароджених необхідно зауважити, що для даних параметрів $\epsilon$ характерно не синхронність процесів їх змін, для них притаманні періоди прискореного та уповільненого їх збільшення. Для поперечної довжини черепа, ширини лиця та висоти черепа виявлено два періоди прискореного розвитку з 6-го по 8-й місяці внутрішньоутробного розвитку та з 9-го місяця розвитку до періоду новонародженості та два періоди сповільненого розвитку - 3 5-го до 6-го місяця та 3 8-го до 9-го місяці внутрішньоутробного розвитку. Щодо загальної висоти лиця, періоди прискореного розвитку - 3 4-го по 6-й місяці розвитку та 3 7-го до 9-й місяця внутрішньоутробного розвитку, періоди сповільненого розвитку - 3 6-го до 7-го місяця розвитку та з 9-го місяця внутрішньоутробного розвитку до періоду новонародженості.

Провівши порівняння середніх значень всіх морфометричних параметрів поперечної довжини черепа, ширини лиця, висоти черепа, загальної висоти лиця у всіх вікових групах з використанням тесту Вілкоксона можна констатувати, що всі p-value більші, ніж рівень значимості $\alpha=0,05$, що означає відсутність значимої різниці. Отже, на основі середніх арифметичних даних поперечної довжини черепа, ширини лиця, висоти черепа, загальної висоти лиця, побудовані моделі прогнозування нормативних морфометричних їх параметрів у плодів та новонароджених, використавши вік плода та тім'яно-п'яткову його довжину. 
Модель поперечної довжини черепа у плодів та новонароджених має вигляд: поперечна довжина черепа $=\beta_{0}+0,224 \mathrm{x}$ тім'яноп'яткова довжина плода, де $\beta_{0}: 3,412$, якщо віковий період $=4$ міс; $1,399=5$ міс; $11,111=6$ міс; $10,918=7$ міс; $13,490=8$ міс; 21,439 = 9 міс; 19,868 = 10 міс; 15,197 = Новонароджені. Коефіцієнт детермінації моделі становить $96,34 \%$.

Модель ширина лиця у плодів та новонароджених має вигляд:

Ширина лиця $=\beta_{0}+0,071 \mathrm{x}$ тім'яно-п'яткова довжина плода, де $\beta_{0}$ : 22,000 , якщо віковий період $=4$ міс; $24,544=5$ міс; $21,351=6$ міс; 22,338 $=7$ міс; $24,975=8$ міс; $19,808=9$ міс; $26,315=10$ міс; 28,607 = Новонароджені. Коефіцієнт детермінації моделі становить 86,84 \%.

Модель висоти черепа у плодів та новонароджених має вигляд:

Висота черепа $=\beta_{0}+0,030 \mathrm{x}$ тім'яно-п'яткова довжина плода, де $\beta_{0}: 41,267$, якщо віковий період $=4$ міс; 46,882 = 5 міс; $44,935=6$ міс; 49,297 $=7$ міс; 55,693 $=8$ міс; 50,790 $=9$ міс; 57,358 = 10 міс; 58,241 = Новонароджені. Коефіцієнт детермінації моделі становить $82,19 \%$.

Модель загальної висоти лиця у плодів та новонароджених має вигляд:

Загальна висота лиця $=\beta_{0}+0,021 \times$ тім'яно-п'яткова довжина плода, де $\beta_{0}: 21,281$, якщо віковий період $=4$ міс; $23,176=5$ міс; $24,515=6$ міс; $23,126=7$ міс; $24,800=8$ міс; 30,194 $=9$ міс; $31,141=10$ міс; $30,940=$ Новонароджені. Коефіцієнт детермінації моделі становить 90,85 \%.

Висновок. Отже, упродовж плодового періоду онтогенезу та у період новонародженості поперечна довжина черепа збільшується з 45,13 $\pm 1,17$ мм плоди 4-го місяця до 96,69 $\pm 0,64$ мм у новонароджених, ширина лиця - $335,23 \pm 0,37$ мм до $64,09 \pm 0,29$ мм, висота черепа - $346,79 \pm 0,74$ мм до $73,04 \pm 0,38$ мм, загальна висота лиця - $325,23 \pm 0,52$ мм до 41,53 $\pm 0,39$ мм відповідно.

\section{Література:}

1. Radosevic D, Maric D \& Ivanovic D. Human skull base asymmetry analysis. Int. J. Morphol., 38(6):1566-1570, 2020.

2. Pelé A, Berry PA, Evanno C, Jordana F. Evaluation of Mental Foramen with Cone Beam Computed Tomography: A Systematic Review of Literature. Radiol Res Pract. 2021 Jan 6;2021:8897275. doi: 10.1155/2021/8897275. PMID: 33505723; PMCID: PMC7806401.

3. Hutchinson EF, Florentino G, Hoffman J, Kramer B. Micro-CT assessment of changes in the morphology and position of the immature 
mandibular canal during early growth. Surg Radiol Anat. 2017 Feb;39(2):185194. doi: 10.1007/s00276-016-1694-x. Epub 2016 May 13. PMID: 27177907.

4. Ercikti N, Apaydin N, Kirici Y. Location of the infraorbital foramen with reference to soft tissue landmarks. Surg Radiol Anat. 2017 Jan;39(1):1115. doi: 10.1007/s00276-016-1683-0. Epub 2016 May 4. PMID: 27146295.

5. Smit S, Hutchinson EF, Kramer B. A morphometric analysis of the immature human infraorbital canal. Surg Radiol Anat. 2021 Feb;43(2):201-10. doi: 10.1007/s00276-020-02563-y. Epub 2020 Sep 12. PMID: 32918571.

DOI https://doi.org/10.30525/978-9934-26-113-8-23

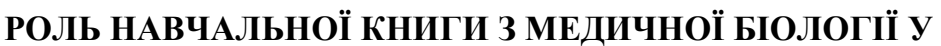 ФОРМУВАННІ ПРИРОДНИЧО-НАУКОВОЇ КОМПЕТЕНЦІЇ В СТУДЕНТІВ ЗАКЛАДУ ВИЩОЇ МЕДИЧНОЇ ОСВІТИ
}

\author{
Кравчук М. Г. \\ кандидат медичних наук, \\ дочент кафедри біології \\ Національний медичний університет імені О. О. Богомольия \\ Гурняк О. М. \\ кандидат біологічних наук, \\ стариий викладач кафедри біології \\ Національний медичний університет імені О. О. Богомольия \\ Романенко О. В. \\ доктор біологічних наук, професор, \\ завідувач кафедри біології \\ Національний медичний університет імені О. О. Богомольця
}

\section{Алексіснко В. Р.}

кандидат біологічних наук, асистент кафедри біології

Національний медичний університет імені О. О. Богомольия м. Київ, Україна

Підготовка висококваліфікованих фахівців, зокрема, 3 фізичної терапії та ерготерапії, належить до пріоритетних завдань медичної освіти 